\title{
Ecology and demography of the Critically Endangered Kandian torrent toad Adenomus kandianus: a long-lost endemic species of Sri Lanka
}

\author{
Suranjan Karunarathna, Sujan Henkanaththegedara, Dinesh Gabadage \\ Madhava Botejue, Majintha Madawala and Thilina D. Surasinghe
}

\begin{abstract}
The tropical island nation of Sri Lanka is a biodiversity hotspot with a high diversity and endemism of amphibians. The endemic, stream-dwelling Kandian torrent toad Adenomus kandianus is Critically Endangered and was considered to be extinct until its rediscovery in 2012 . The species is now known from two localities in tropical montane forests. We conducted a 4-year study using transect surveys and opportunistic excursions to assess habitat associations, demographics and abundance of $A$. kandianus in and around Pidurutalagala Conservation Forest. We recorded a mean of 44.25 post-metamorphs per year, with a density of $<_{1}$ individual per $100 \mathrm{~m}^{2}$, with occurrence within a narrow extent (c. $0.005 \mathrm{~km}^{2}$ ) of the stream channel. Behaviour and microhabitat selection varied depending on sex and stage of maturity. The species preferred moderately sized montane streams with rocky substrates and woody debris, colder temperatures, and closed-canopy, intact riparian forests. We noted size-based reversed sexual dimorphism and a strong ontogenetic relationship between snout-vent length and body weight. Anthropogenic activities such as intensive crop farming deterred the species; proximity to croplands had a negative influence on abundance. We recommend re-delineation of the boundary of Pidurutalagala Conservation Forest to incorporate the toad's habitat into the core of the reserve and thus limit the impacts of human activities. Conservation and management actions such as ex-situ breeding, population monitoring, and restoration of degraded habitats could also contribute towards the persistence of this toad. Our findings provide useful insights into ecological research on and conservation of range-restricted aquatic amphibians.
\end{abstract}

\footnotetext{
Suranjan Karunarathna Nature Explorations \& Education Team, Soysapura Flats, Moratuwa, Sri Lanka

Sujan Henkanaththegedara Department of Biological \& Environmental Sciences, Longwood University, Virginia, USA

Dinesh Gabadage and Madhava Botejue Biodiversity Conservation Society, Nugegoda, Sri Lanka

Majintha Madawala No. 18 Ratmal Mawatha, Sirimal Uyana, Ratmalana, Sri Lanka

Thilina D. Surasinghe (Corresponding author) Department of Biological Sciences, Bridgewater State University, Bridgewater, MA 02325, USA

E-mail tsurasinghe@bridgew.edu

Received 13 February 2016. Revision requested 11 May 2016.

Accepted 24 May 2016. First published online 28 October 2016.
}

Keywords Adenomus kandianus, Amphibia, Bufonidae, conservation, Critically Endangered, montane streams, Sri Lanka, tropical rainforests

\section{Introduction}

The South Asian tropical island of Sri Lanka is rich in 1 amphibian diversity (Meegaskumbura et al., 2002). Of the country's 119 described amphibian species 104 (c. $87 \%$ ) are endemic and $>90 \%$ are restricted to rainforests (Surasinghe, 2009; Wickramasinghe et al., 2015). Sri Lanka's amphibians are threatened by deforestation, environmental pollution and road traffic (Pethiyagoda et al., 2006; Karunarathna et al., 2013). These anthropogenic stressors have contributed to the extinction of 18 amphibian species, and declining populations of nearly half of the extant species (MOE, 2012).

The stream-dwelling toad genus Adenomus contains two species, Kelaart's torrent toad A. kelaartii and the Kandian torrent toad A. kandianus (Meegaskumbura et al., 2015a). The latter was considered to be extinct for 136 years (Stuart et al., 2008) until its rediscovery at Peak Wilderness Sanctuary in 2012 (Wickramasinghe et al., 2012). Currently, this species is known from only two localities in the Central Highlands $(>1,400 \mathrm{~m}$; Gabadage et al., 2014) and it is categorized as Critically Endangered on the IUCN Red List (IUCN SSC Amphibian Specialist Group, 2012). The species' molecular phylogeny, bioacoustics, osteology, and larval and adult morphology have been studied (Meegaskumbura et al., 2015a,b).

In the literature on A. kandianus, details about the species' natural history, habitat associations, behaviour and population status are limited. This paucity of ecological information impedes conservation action. We therefore studied the population abundance, behaviour, body size variation with sex and sexual maturity, and microhabitat associations and environmental correlations of $A$. kandianus. Our findings will help inform future conservation action for this Critically Endangered species and provide a foundation for future research.

\section{Study area}

The study area is located partly in the buffer zone of Pidurutalagala (Mount Pedro) Conservation Forest in 


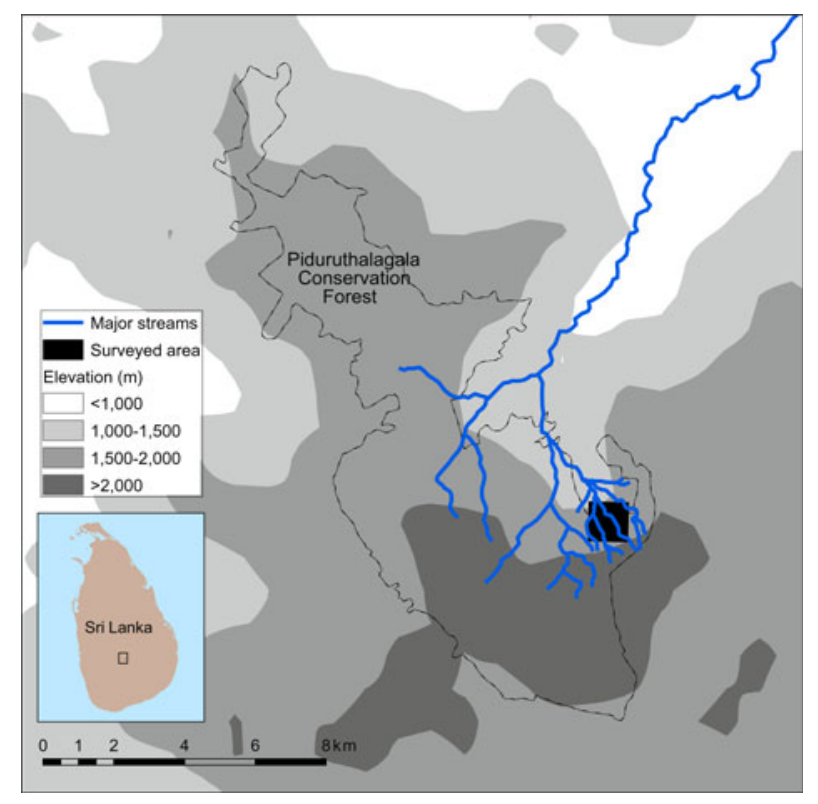

FIG. 1 The location of the study site in Pidurutalagala Conservation Forest in the Central Highlands of Sri Lanka.

Sri Lanka's Central Highlands (Fig. 1), one of the two localities from where A. kandianus is known (Gabadage et al., 2014). Although the forest is under governmental jurisdiction, its buffer zone is imperilled by a multitude of anthropogenic disturbances, the most detrimental being clear-cutting (Plate 1). It is one of the largest montane protected areas in Sri Lanka $(7,625.29 \mathrm{ha})$ and is also a UNESCO World Heritage Site (UNESCO, 2016). The mean annual precipitation is $>3,000 \mathrm{~mm}$, and mean annual temperature is $18{ }^{\circ} \mathrm{C}$ (Gabadage et al., 2014).

\section{Methods}

Survey design We conducted 1-week-long field excursions annually during 2011-2013 and twice in 2014. Surveys were conducted in the morning (07.00-14.00) and evening (18.00-20.00) to account for both diurnal and nocturnal activities. Across the entire survey period we surveyed both during (April, May, August) and outside (October, December) the monsoon season. In addition to transect surveys we made opportunistic observations. Statistical analyses were based only on the transect surveys. We placed $15100 \times 5 \mathrm{~m}$ belt transects along stream habitats, which covered stream channels and adjacent woodlands, with a minimum distance of $40 \mathrm{~m}$ between neighbouring transects. The four-person survey team walked along the transects, actively searching and visually scanning for amphibians. Active searching included examining leaf litter, superficial roots and tree trunks, and understorey vegetation, lifting movable rocks and woody debris, and searching the stream channel (riffles and pools) and cascades using hand $(50 \times 30 \mathrm{~cm})$ and seine nets $(1 \times 3 \mathrm{~m})$. For each individual found we recorded sex (based on the presence or absence of nuptial pads and gular sacs), snout-vent length (using a digital vernier caliper), stage of maturity (based on snout-vent length: juvenile $\leq 21 \mathrm{~mm}$, adult $\geq 29 \mathrm{~mm}$ ), and blotted wet weight (using a Taylor spring scale). Measuring blotted wet weight eliminates excess water on skin surface. All captured individuals were released to the wild without harm at the point of capture.

Environmental variables Where toads were found we recorded the following environmental variables: stream width, canopy cover (using a canopy densiometer), water and air temperature (using a standard mercury thermometer), relative humidity and light intensity (using a Digitech QM1594 6-in-1 multifunction environment meter), and $\mathrm{pH}$ (using a Digitech QM-1670 pH meter). We measured the length of boulders at the intermediate axis, and the above-water height of emergent boulders, pool depth, and the Euclidean distance from each toad to the nearest cultivated land. We obtained rainfall data from the nearest weather station (National Meteorological Department, Sri Lanka). Additionally, we observed the surrounding habitat and recorded any evidence of anthropogenic disturbance.

Behavioural observations We noted the behaviour of each toad at the time of observation, as well their microhabitat and substrate use.

Statistical analysis To test for differences in relative abundance among age-sex categories (male, female, juveniles) we ran a one-way ANCOVA (analysis of covariance) in which abundance was considered to be the response variable, the age-sex category was the treatment, and rainfall and sampling dates were covariates. Pairwise differences in abundance of age-sex groups were tested using a Tukey HSD (honest significant difference) test. To test for differences in body size among age-sex categories we used one-way ANOVA (analysis of variance) in which the age-sex category was considered to be the treatment and snout-vent length and blotted wet weight were response variables. A post-hoc Tukey test was performed to discern pairwise differences among age-sex groups for blotted wet weight and snout-vent length. We constructed a linear regression model to test for a significant relationship between the snout-vent length and blotted wet weight. We used a $\chi^{2}$ test of independence to detect any influence of sex on behavioural acts or habitat use. Based on a $\chi^{2}$ test for goodness of fit, we tested if the behavioural acts and habitat use were distributed evenly among individuals. To test for the importance of various environmental variables on the abundance of toads, we constructed a stepwise multiple 

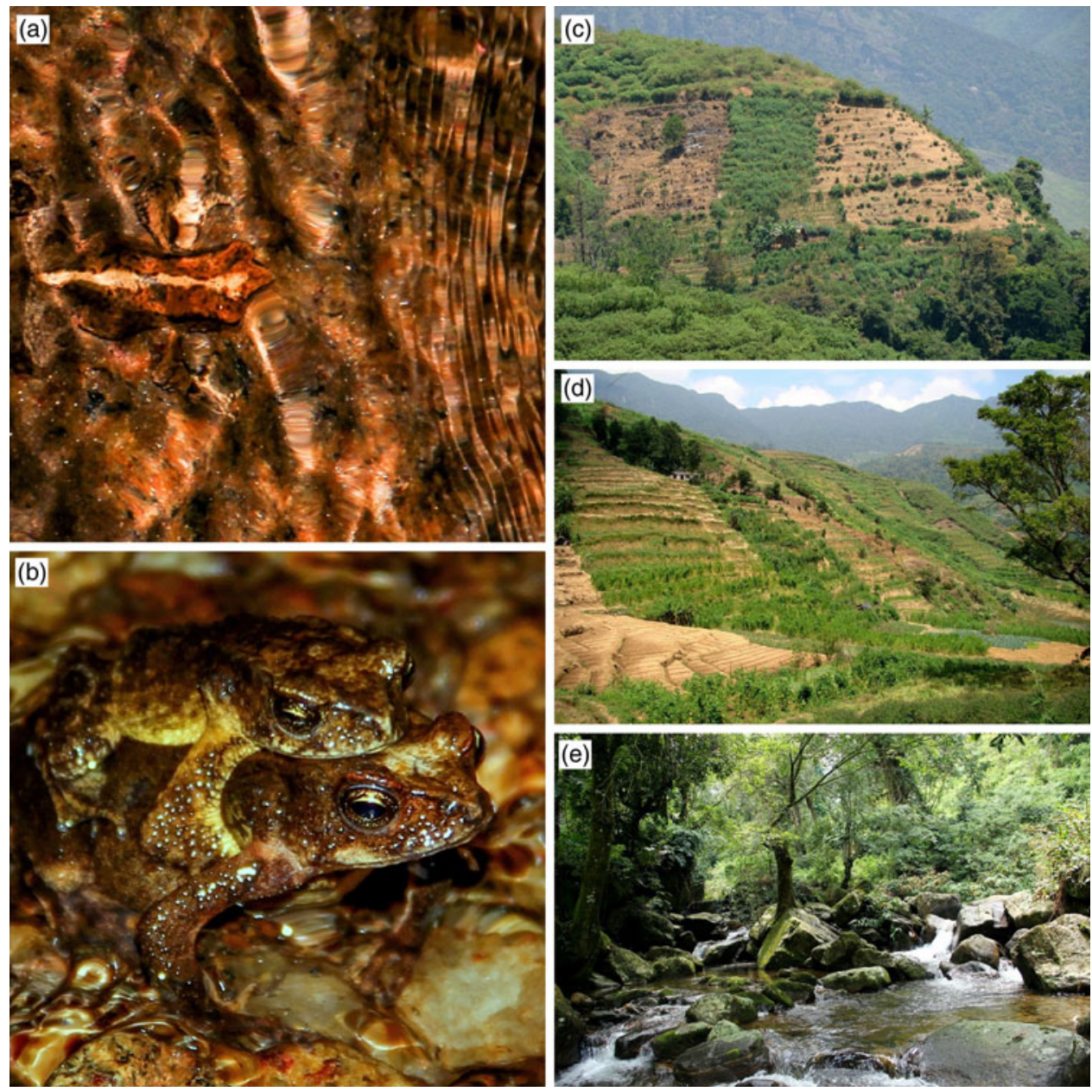

Plate 1 (a) Adenomus kandianus underwater, camouflaged against the rocky streambed, (b) male (on top) and female Adenomus kandianus in amplexus, (c) and (d) plantation agriculture and deforestation around Pidurutalagala Conservation Forest, and (e) the stream segment at Pidurutalagala Conservation Forest, one of two known localities of Adenomus kandianus. regression model (a mixed-model approach) in which all the environmental variables were considered to be predictor variables and the abundance of toads was the response variable. Statistical analyses were conducted using various packages (ANCOVA: aov; linear regression: $l m$; and $\chi^{2}$ test: chisq.test) in $R$ v. 2.15.o (R Development Core Team, 2011).

\section{Results}

The transects covered a total area of $0.1 \mathrm{~km}^{2}$, in which we recorded $A$. kandianus only in a $10 \times 500 \mathrm{~m}\left(0.005 \mathrm{~km}^{2}\right)$ stretch of a medium-sized fast-flowing perennial montane stream. The toads were found only along the stream channel, including undercut banks, and never in the woodlands. Our opportunistic surveys of other neighbouring streams, wetlands and forests did not reveal any persistent populations of the species.

\section{Total abundance}

We recorded a total of 169 individuals, with a mean of 24.5 males, 13 females and 6.75 juveniles per year (Table 1). The overall population density was $0.85 \pm$ SD 0.57 individuals per $100 \mathrm{~m}^{2}$. Abundance differed significantly among the age-sex groups $(F=3.69, \mathrm{P}<0.05)$; effects of rainfall $(F=8.07, \quad \mathrm{P}<0.05)$ and date surveyed $(F=10.09$, $\mathrm{P}<0.05)$ were significant covariates. The abundance of males was significantly higher than that of females (mean difference $=1.33, \mathrm{P}<0.05$ ). The differential mean abundance between males and juveniles (mean difference $=0.83$, $\mathrm{P}>0.05)$ and between females and juveniles was not significant (mean difference $=0.50, \mathrm{P}>0.05$ ). The population was male-skewed (male: female $=2: 1$ ) throughout the study, except in $2013(1: 3)$.

\section{Behaviour and microhabitat use}

Behavioural acts we observed included perching on boulders, mating in a variety of microhabitats (boulders, submerged in water), swimming, and seeking refuge (Table 2). Age-sex category had a significant influence on behavioural acts $\left(\chi^{2}=93.62, \mathrm{P}<0.05\right)$. Behavioural acts were not observed uniformly among toads $\left(\chi^{2}=46.71\right.$, $\mathrm{P}<0.05)$. Perching was the most commonly observed behavioural act among males, followed by mating. Among females, mating was the most dominant behavioural act 
TABle 1 Mean number of females, males and juveniles of Adenomus kandianus recorded per transect in Pidurutalagala Conservation Forest, Sri Lanka (Fig. 1), in each of 4 sampling years (2011-2014).

\begin{tabular}{lcccc}
\hline Sampling year & No. of females \pm SD & No. of males \pm SD & No. of juveniles \pm SD & Total \pm SD \\
\hline 2011 & $3 \pm 0.45$ & $8 \pm 0.49$ & $3 \pm 0.45$ & $14 \pm 0.39$ \\
2012 & $29 \pm 3.78$ & $47 \pm 4.49$ & $12 \pm 0.51$ & $88 \pm 7.21$ \\
2013 & $6 \pm 0.51$ & $2 \pm 0.35$ & $7 \pm 0.52$ & $15 \pm 0$ \\
2014 & $14 \pm 0.43$ & $41 \pm 1.69$ & $5 \pm 0.34$ & $60 \pm 2.01$ \\
Mean per year & $13 \pm 10.07$ & $24.5 \pm 19.73$ & $6.75 \pm 3.34$ & $44.25 \pm 28.64$ \\
\hline
\end{tabular}

TABLE 2 Percentage of female, juvenile and male individuals of Adenomus kandianus recorded mating, perching, seeking refuge, and diving and swimming during surveys in Pidurutalagala Conservation Forest (Fig. 1).

\begin{tabular}{llcc}
\hline Behaviour & Females (\%) & Juveniles (\%) & Males (\%) \\
\hline Mating & 82.69 & 0 & 40.57 \\
Perching & 11.54 & 3 & 44.33 \\
Seeking refuge & 0 & 97 & 0 \\
Diving \& swimming & 5.77 & 0 & 15.10 \\
\hline
\end{tabular}

(Table 2). In a number of instances juveniles emerged from undercut banks at dusk (18.00-19.0o) and perched at the stream edge in groups of 2-4. Neither males nor females were observed in refuge. The juveniles had only partially developed webbing in their feet and thus were weak swimmers. Adults had complete webbing and were strong swimmers, and swam perpendicular to the flow.

The toads were found in five microhabitats: (1) on mosscovered boulders (most of the time, underneath leaf litter on the boulders), (2) in pools with decaying organic matter, (3) in pools with a sandy substrate, (4) in riffles with a rockycobble-pebble substrate, and (5) in undercut banks, among leaf litter and roots of riparian vegetation (Table 3). Toads did not occur uniformly across all microhabitats $\left(\chi^{2}=25.89, \mathrm{P}<0.05\right)$; microhabitat use was dependent on the age-sex category $\left(\chi^{2}=95.22, \mathrm{P}<0.05\right)$. Both males and females were found mostly on moss-covered boulders (Table 3). A substantial proportion of adults were also found in in-stream pools. A few adults were observed actively swimming across fast-flowing riffles. Neither adults nor juveniles were found in the riparian zone or in woodlands. Juveniles were found almost exclusively at the edge of the stream channel, within the leaf litter or finely branched roots of the riparian vegetation in undercut banks. We did not observe any juveniles cohabiting with adults in the same microhabitat.

Advertisement calls and mating (amplexus) were recorded only during April-May in each year. On a given day, calling started at 18.00 and continued until 20.00. Toads were calling from mid-stream, while perching on boulders. Precipitation was associated with increased incidence of observed mating; for example, on a rainy day in
2012 we observed 17 amplexed pairs in a single in-stream pool along with 15 advertising males, the only breeding congregation we recorded throughout our survey. Amplexus was observed in a variety of microhabitats: underwater, on emergent parts of moss-covered boulders, and in the leaf litter on moss-covered boulders. We found no egg masses during our survey. Amplexus lasted for 4 hours on average but some amplexed pairs remained in position at the same location for 8 hours. On each of five different occasions we observed five amplexed pairs swimming continuously for 3.5 minutes (Plate 1). On 10 occasions we observed non-mating toads swimming as a group. Individuals remained underwater for a mean of 20 minutes.

\section{Body size variation}

Both snout-vent length and blotted wet weight differed significantly among age-sex categories (Table 4). Females were significantly larger than males and juveniles in terms of both snout-vent length and blotted wet weight. Males were significantly larger than juveniles in terms of snout-vent length. There was a strong linear length-weight relationship among all age-sex categories (linear regression model, $R^{2}=0.9012 ; F=356.9 ; \mathrm{P}<$ 0.0001; Fig. 2).

\section{Environmental variables}

The environmental variables indicated an association between $A$. kandianus and microhabitats with higher canopy cover $(>68 \%)$, cooler air temperatures $\left(<26^{\circ} \mathrm{C}\right)$, lower light intensity $(<33$ lux $)$ and high humidity $(>71 \%)$ (Table 5). The low-order montane stream in which we found the species was $\operatorname{cool}\left(17^{\circ} \mathrm{C}\right)$, fast-flowing and mediumsized ( $6 \mathrm{~m}$ in width), with multiple pools and riffles and near-neutral $\mathrm{pH}$ (6.14). The stream channel contained boulders of various sizes (1-8 $\mathrm{m}$ in length), which were continually splashed by the turbulent flow. The stream substrate comprised cobbles and pebbles, leaf litter and sand. Given the reduced flow, pool habitats had accumulated silt, sediment and organic matter (coarse woody debris).The best predictors of the abundance of A. kandianus were the Euclidean distance to the nearest cropland, and the ambient 
TABLE 3 Percentage of female, juvenile and male individuals of Adenomus kandianus occupying various microhabitats in Pidurutalagala Conservation Forest (Fig. 1).

\begin{tabular}{|c|c|c|c|}
\hline Microhabitat & Females (\%) & Juveniles (\%) & Males (\%) \\
\hline Moss-covered boulders in stream channel & 77.35 & 0 & 72.34 \\
\hline Pools with a decaying organic-matter substrate & 20.15 & 0 & 11.27 \\
\hline Pools with a sandy substrate & 0 & 0 & 13.19 \\
\hline Riffles with rocky-cobble-pebble substrate & 2.5 & 0 & 3.2 \\
\hline Undercut banks with leaf litter \& complex root structure of riparian vegetation & 0 & 100 & 0 \\
\hline
\end{tabular}

TABLE 4 Differences in snout-vent length and blotted wet weight among females, males and juveniles of Adenomus kandianus, with ANOVA and Tukey statistics.

\begin{tabular}{|c|c|c|c|c|c|c|}
\hline & Female & Male & Juvenile & F statistics (ANOVA) & Tukey statistics & \\
\hline \multirow[t]{3}{*}{ Blotted wet weight \pm SD (g) } & $3.51 \pm 0.11$ & $2.41 \pm 0.14$ & $1.76 \pm 0.11$ & $387.25^{*}$ & Female-Male & $1.10^{*}$ \\
\hline & & & & & Female-Juvenile & $1.75^{\star}$ \\
\hline & & & & & Male-Juvenile & $0.65^{\star}$ \\
\hline \multirow[t]{3}{*}{ Snout-vent length $\pm \mathrm{SD}(\mathrm{mm})$} & $41.16 \pm 0.53$ & $30.78 \pm 0.47$ & $19.62 \pm 0.56$ & $3,172.61^{\star}$ & Female-Male & $10.37^{\star}$ \\
\hline & & & & & Female-Juvenile & $21.54^{\star}$ \\
\hline & & & & & Male-Juvenile & $11.16^{*}$ \\
\hline
\end{tabular}

${ }^{*} \mathrm{P}<0.05$

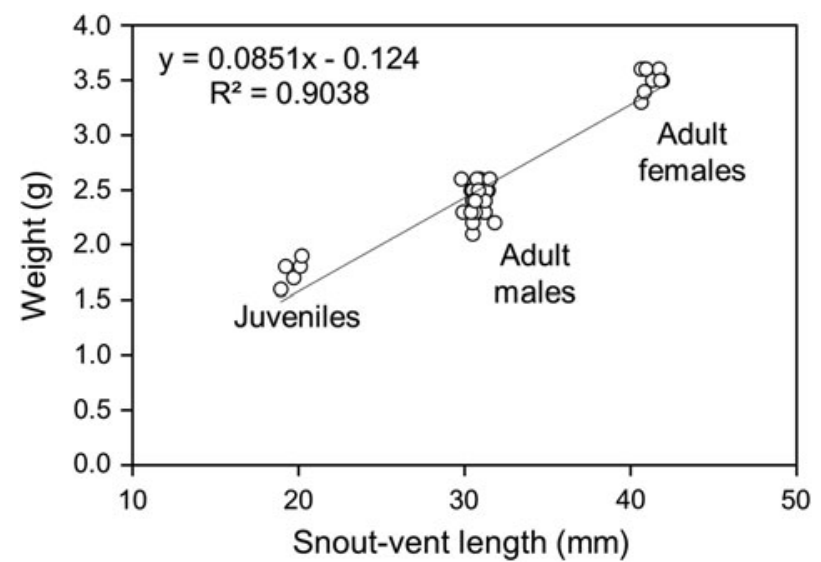

FIG. 2 Length-weight relationship for adult females, adult males and juveniles of Adenomus kandianus in Pidurutalagala Conservation Forest, Sri Lanka, based on a linear regression of snout-vent length (SVL) against blotted wet weight $\left(R^{2}=0.9012\right.$, $F=356.9, \mathrm{P}=0.0001)$.

temperature (stepwise multiple regression, $R^{2}=0.997$, $F=729.96, \mathrm{P}<0.05)$; the former was the most influential variable (model coefficients: distance to croplands $=0.97$, ambient temperature $=0.08$ ). Partial correlation analyses revealed that rainfall, relative humidity, canopy cover, water temperature and size of boulders had the highest influence on the abundance of toads (Table 5).

\section{Observations of tadpoles}

We observed a mean of only 11 tadpoles per year in in-stream pools. All tadpoles were found completely submerged in water
TABLE 5 Mean values of environmental variables measured when individuals of Adenomus kandianus were found during surveys in Pidurutalagala Conservation Forest (Fig. 1), with partial correlation coefficients between the abundance of toads and environmental variables extracted from a stepwise multiple regression model.

\begin{tabular}{lcc}
\hline Variable & Mean $\pm \mathrm{SD}$ & $\begin{array}{l}\text { Partial correlation } \\
\text { coefficients }\end{array}$ \\
\hline Canopy cover $(\%)$ & $68.38 \pm 1.41$ & 0.71 \\
Cloud cover $(\%)$ & $37.03 \pm 1.48$ & 0.505 \\
Air temperature $\left({ }^{\circ} \mathrm{C}\right)$ & $25.36 \pm 0.14$ & $-0.98^{*}$ \\
Water temperature $\left({ }^{\circ} \mathrm{C}\right)$ & $17.16 \pm 0.13$ & -0.75 \\
Monthly rainfall $(\mathrm{mm})$ & $305.41 \pm 17.35$ & 0.83 \\
Relative humidity $(\%)$ & $72.00 \pm 1.50$ & 0.87 \\
Water pH & $6.14 \pm 0.03$ & 0.39 \\
Illuminance $(\mathrm{lux})$ & $32.00 \pm 2.83$ & 0.45 \\
Stream width $(\mathrm{m})$ & $6.08 \pm 0.54$ & 0.29 \\
Euclidean distance to & $57.23 \pm 14.48$ & $0.99^{*}$ \\
nearest cropland & & \\
Size of in-stream & $4.5 \pm 3.5$ & 0.75 \\
boulders (m) & & \\
Height of submerged & $1.58 \pm 1.1$ & 0.56 \\
boulders (m) & & \\
\hline
\end{tabular}

${ }^{\star} \mathrm{P}<0.05$

and were attached to rocky substrates by their oral discs. Their bodies were dark-brown to black in coloration.

\section{Discussion}

In our surveys in both wet and dry seasons over 4 years we recorded only c. 44 post-metamorphs in any given year. The 
overall density was low $\left(<_{1}\right.$ individual per $\left.100 \mathrm{~m}^{2}\right)$ and the area of occupancy did not extend beyond a stream corridor of $0.005 \mathrm{~km}^{2}$. Similar demographic characteristics have been reported for other threatened, narrow-ranging tropical amphibians (Sodhi et al., 2008). We found neither eggs nor gravid females, and only a small number of juveniles and tadpoles. Although no egg masses were observed at Peak Wilderness (the only other known habitat of A. kandianus), gravid females were recorded there (Meegaskumbura et al., 2015b). Unlike adults, tadpoles and juveniles are weak swimmers and may not withstand the heightened discharge after torrential precipitation, and therefore they may have been washed downstream (Meegaskumbura et al., 2015b). This speculation was substantiated by our opportunistic observations of juveniles in lower altitude paddy fields after heavy rainfall. Adenomus kandianus is a specialist toad adapted to montane, undisturbed forested streams, and therefore tadpoles and juveniles transported into anthropogenic environments are unlikely to survive. As a protective measure (to prevent downstream drift, predation, ambient exposure and radiation damage) adults may oviposit in protected, deep interstices, which are undetectable by surveys (Refsnider \& Janzen, 2010). Low abundance of larval and juvenile stages may indicate lower recruitment rates and lower survival of early age classes. During surveys we found dragonfly larvae in the stream; these macroinvertebrates could predate on early life stages of $A$. kandianus, leading to higher mortality among tadpoles and juveniles (Skelly, 1994).

There was a strong positive correlation between snoutvent length and blotted wet weight, indicating an ontogenic relationship. Distinct size segregation among various agesex categories indicates that body dimensions are sexually dimorphic features for this species. Larger body size of females compared to males (reversed size-based sexual dimorphism) has been observed in many anurans (Woolbright, 1983). Among basal vertebrates, large females may produce a greater number of eggs, reproducing early in the season, which may ensure early metamorphosis of large juveniles; larger body size confers higher fecundity, timely reproduction and a high juvenile survival rate, and thus higher reproductive fitness overall (Tejedo, 1992).

Microhabitat use and behaviour differed substantially between adults and juveniles: adults were mostly observed mating or perching, whereas juveniles were seeking refuge. Niche partitioning within conspecifics, such as microhabitat and resource specialization, can mitigate offspring-adult competition (Meegaskumbura et al., 2015a). A closed canopy, high humidity, low temperatures, intermediate-sized boulders, and absence of anthropogenic disturbances were important environmental conditions for A. kandianus. These ecological niche dimensions are peculiar to many rainforest amphibians (Pethiyagoda et al., 2006). The dependence on well-shaded canopy, colder temperatures and high humidity implies that this species is susceptible to desiccation. Medium-sized, moist boulders are likely to be preferred sites for advertisement calls. During surveys we observed a few potential predators of $A$. kandianus: Tickell's blue flycatcher Cyornis tickelliae, Sri Lanka whistling thrush Myophonus blighi, Indian blackbird Turdus simillimus, Sri Lanka hill myna Gracula ptilogenys and river otter Lutra lutra. Prolonged amplexus may predispose A. kandianus to predation where leaf litter on boulders provides concealment.

Species detectability may have played a significant role in our study. Precipitation and seasonality influenced abundance and breeding of A. kandianus, and may also have influenced the species' detectability and site occupancy. We are unaware of any refugia used by toads when they are inactive. It is possible that these toads use subterranean burrows or deep crevices in the stream bed that were undetectable by our surveys.

\section{Threats and conservation}

In contrast to our findings, surveys at Peak Wilderness revealed that females occurred outside the stream channel (Meegaskumbura et al., 2015a,b). It was implied that the species may not be rare, at least at the Peak Wilderness locality, given en masse reproduction and high tadpole densities. There has been relatively less habitat destruction at the Peak Wilderness locality compared to Pidurutalagala Conservation Forest. We recorded the presence of multiple commercial plantations (e.g. banana, tea, cardamom, tomato, cabbage, beans) during our study. In addition, clearcut forestlands, gem and graphite mining, heavy extraction of non-timber forest products, and canopy dieback were also observed in close proximity to our study site. These anthropogenic stressors may have impaired the reproductive fitness of A. kandianus, and precluded local movements in upland habitats.

Ongoing deforestation and agricultural expansion may lead to higher rates of soil erosion; subsequent siltation and sedimentation in stream channels could smother eggs and destroy larval feeding grounds (Richter et al., 1997). We observed the use of agrochemicals on nearby croplands, which can enter the stream habitat through surface run-off and result in developmental abnormalities, growth retardation, delayed metamorphosis and increased egg and larval mortality (Sampath et al., 2002). We also noted that some invasive plant species had colonized the riparian forests and adjoining woodlands. Anthropogenic disturbance such as forest clearing and crop farming may have facilitated the establishment of these species (Didham et al., 2005).

Our extensive survey confirmed that at Pidurutalagala Conservation Forest $A$. kandianus is restricted to a narrow stretch $\left(0.005 \mathrm{~km}^{2}\right)$ of a perennial mountain stream. 
Fluctuating abundance implies instability of the population. Relatively small, isolated populations are susceptible to both demographic and environmental stochasticity, and human disturbances can cause further decline and result in an extinction vortex (Sodhi et al., 2008). Although ecological niche modelling predicted a potential distribution range of c. $650 \mathrm{~km}^{2}$ for the species, only $20 \mathrm{~km}^{2}$ of suitable habitat was available within the predicted range (Meegaskumbura et al., 2015b). Thus, it is possible to infer a population decline of $>80 \%$ within the past decade. Like many amphibians A. kandianus faces a high risk of extinction because of ecophysiological constraints, high habitat specialization, poor dispersal capacity and high site fidelity (Blaustein et al., 1994). Our findings support the species' current IUCN categorization as Critically Endangered. Despite the narrow area of occupancy, no national-level actions have been implemented to protect this toad. Our study area falls partly within the buffer zone of Pidurutalagala Conservation Forest, where multiple uses and human activities are permitted. We recommend that this vital stream habitat and the surrounding woodlands be incorporated into the core habitat of the reserve, thus shifting the buffer zone to a lower altitude.

It is crucial to protect both the immediate riparian zone and the surrounding woodlands to sustain watershed-scale ecological processes such as provision of allochthonous materials (Olson et al., 2007). Delineating a core and a terrestrial buffer around streams may negate the adverse effects of agriculture (Semlitsch \& Bodie, 2003). Pidurutalagala is a unique montane rainforest rich in endemic native biodiversity and threatened by human activities (Werner, 1988), and we recommend that it be incorporated into Sri Lanka's Central Highlands UNESCO World Heritage Site. Given the presence of a Critically Endangered species, headwater streams and anthropogenic stressors, we recommend upgrading the forest to a Strict Nature Reserve, where actions can be taken to restrict human impacts, implement continuous monitoring and scientific research, and promote ecosystem-wide biodiversity conservation (Dudley, 2008).

\section{Conclusion}

Future studies should focus on enumerating the abundance of tadpoles, juveniles and subadults, population viability analyses, and the reproductive biology of A. kandianus, so that scientifically robust inferences can be made about the species' population dynamics. Given that A. kandianus is now limited to two known populations, both small, we recommend a preliminary attempt at captive breeding and ex situ conservation. Given the species' cryptic nature and seasonality we recommend that any future surveys use occupancy modelling to account for imperfect detection.

Our research methods could serve as a model for ecological studies on other less-studied, threatened, range-restricted amphibians. The conservation actions we recommend could be adapted for other threatened aquatic species, especially those of tropical montane streams, where there is a need for science-based conservation.

\section{Acknowledgements}

We express our sincere gratitude to Anslem de Silva, Thasun Amarasinghe, Kelum Manamendra-Arachchi, Mendis Wickramasinghe, the Forest Department, the Department of Wildlife Conservation, the National Museum of Sri Lanka (Sanuja Kasthuriarachchi, Nanda Wickramasinghe, Lankani Somaratne, Manori Nandasena, Chandrika Munasinghe and Rasika Dasanayake), and the Young Zoologists' Association for help during this study.

\section{Author contributions}

SK and SH designed the field sampling protocols. SK, DG, MB and MM conducted the fieldwork and data entry. SH and TS conducted the statistical analyses and SH, TS, and SK wrote the article. SH and TS produced the maps, figures and tables. All authors contributed equally in finalizing the manuscript.

\section{References}

Blaustein, A.R., Wake, D.B. \& Sousa, W.P. (1994) Amphibian declines: judging stability, persistence, and susceptibility of populations to local and global extinctions. Conservation Biology, 8, 6o-71.

Didham, R.K., Tylianakis, J.M., Hutchison, M.A., Ewers, R.M. \& Gemmell, N.J. (2005) Are invasive species the drivers of ecological change? Trends in Ecology \& Evolution, 20, 470-474.

Dudley, N. (2008) Guidelines for Applying Protected Area Management Categories. IUCN, Gland, Switzerland.

Gabadage, D.E., De Silva, A., Botejue, W.M.S., Bahir, M.M., Surasinghe, T.D., Madawala, M.B. et al. (2014) On the discovery of second living population of Adenomus kandianus (Günther, 1872) from Sri Lanka: with the bioecology, and detailed redescription to the species. Herpetotropicos, 10, 37-49.

IUCN SSC Amphibian Specialist Group (2012) Adenomus kandianus. The IUCN Red List of Threatened Species 2012: e. T54458A17511456. Http://dx.doi.org/10.2305/IUCN.UK.2012.RLTS. T54458A17511456.en [accessed 18 May 2016].

Karunarathna, D.M.S.S., Henkanaththegedara, S.M., Amarasinghe, A.A.T. \& De Silva, A. (2013) Impact of vehicular traffic on Herpetofaunal mortality in a savannah forest, eastern Sri Lanka. Taprobanica, 5, 111-119.

Meegaskumbura, M., Bossuyt, F., Pethiyagoda, R., Manamendra-Arachchi, K., Bahir, M., Milinkovitch, M.C. \& SCHNeIder, C.J. (2002) Sri Lanka: an amphibian hot spot. Science, 298, 379.

Meegaskumbura, M., Senevirathne, G., Wijayathilaka, N., Jayawardena, B., Bandara, C., Manamendra-Arachchi, K. \& Pethiy agoda, R. (2015a) The Sri Lankan torrent toads (Bufonidae: Adenominae: Adenomus): species boundaries assessed using multiple criteria. Zootaxa, 3911, 245-261.

Meegaskumbura, M., Wijayathilaka, N., Abayalath, N. \& Senevirathne, G. (2015b) Realities of rarity: climatically and 
ecologically restricted, critically endangered Kandian Torrent Toads (Adenomus kandianus) breed en masse. PeerJ PrePrints, 3, e1964.

MOE (Ministry of Environment) (2012) The National Red List 2012 of Sri Lanka; Conservation Status of the Fauna and Flora. Biodiversity Secretariat, Ministry of Environment, Colombo, Sri Lanka.

Olson, D.H., Anderson, P.D., Frissell, C.A., Welsh Jr, H.H. \& BRADFORD, D.F. (2007) Biodiversity management approaches for stream-riparian areas: perspectives for Pacific Northwest headwater forests, microclimates, and amphibians. Forest Ecology and Management, 246, 81-107.

Pethiyagoda, R., Manamendra - Arachchi, K., Bahir, M.M. \& Meegaskumbura, M. (2006) Sri Lankan amphibians: diversity, uniqueness and conservation. In The Fauna of Sri Lanka: Status of Taxonomy, Research and Conservation (ed. C.N.B. Bambaradeniya), pp. 125-133. The World Conservation Union, Colombo, Sri Lanka \& Government of Sri Lanka.

R Development Core Team (2011) R: A Language and Environment for Statistical Computing. R Foundation for Statistical Computing, Vienna, Austria.

Refsnider, J.M. \& Janzen, F.J. (2010) Putting eggs in one basket: ecological and evolutionary hypotheses for variation in oviposition-site choice. Annual Review of Ecology, Evolution, and Systematics, 41, 39-57.

Richter, B.D., Braun, D.P., Mendelson, M.A. \& Master, L.L. (1997) Threats to imperiled freshwater fauna. Conservation Biology, 11, 1081-1093.

Sampath, K., Kennedy, I.J.J. \& James, R. (2002) Pesticide impact on excretory physiology of the common frog, Rana tigrina (Daud) tadpoles. Bulletin of Environmental Contamination and Toxicology, $68,652-659$.

SEMlitsCh, R.D. \& Bodie, J.R. (2003) Biological criteria for buffer zones around wetlands and riparian habitats for amphibians and reptiles. Conservation Biology, 17, 1219-1228.

SKELLY, D.K. (1994) Activity level and the susceptibility of anuran larvae to predation. Animal Behaviour, 47, 465-468.

Sodhi, N.S., Bickford, D., Diesmos, A.C., Lee, T.M., Koh, L.P., BRоок, B.W. et al. (2008) Measuring the meltdown: drivers of global amphibian extinction and decline. PLOS ONE, 3(2), e1636.

Stuart, S.N., Hoffmann, M., Chanson, J.S., Cox, N.A., Berridge, R.J., Ramani, P. \& Young, B.E. (eds) (2008) Threatened Amphibians of the World. Lynx Edicions, Barcelona, Spain.
Surasinghe, T.D. (2009) Conservation and distribution status of amphibian fauna in Sri Lanka. Biodiversity, 10, 3-17.

Tejedo, M. (1992) Effects of body size and timing of reproduction on reproductive success in female natterjack toads (Bufo calamita). Journal of Zoology, 228, 545-555.

UNESCO (2016) World Heritage List. Http://whc.unesco.org/en/list/ [accessed 2 March 2016].

Werner, W. (1988) Human impact on natural environment in the Central Highlands of Sri Lanka. Universitas, 30, 29-37.

Wickramasinghe, L.J.M., Bandara, I.N., Vidanapathirana, D.R., Tennakoon, K.H., Samarakoon, S.R. \& Wickramasinghe, N. (2015) Pseudophilautus dilmah, a new species of shrub frog (Amphibia: Anura: Rhacophoridae) from a threatened habitat Loolkandura in Sri Lanka. Journal of Threatened Taxa, 7, 7089-7110.

Wickramasinghe, L.J.M., VidanapathiRAna, D.R. \& WiCKRAMASINGHE, N. (2012) Back from the dead: the world's rarest toad Adenomus kandianus rediscovered in Sri Lanka. Zootaxa, 3347, 63-68.

Woolbright, L.L. (1983) Sexual selection and size dimorphism in anuran amphibia. The American Naturalist, 121, 110-119.

\section{Biographical sketches}

SURANJAn KarUnarathna is a field biologist, and his research focuses on herpetofaunal ecology, taxonomy and conservation of threatened species. He is an active member of the IUCN Amphibian Specialist Group. Sujan Henkanaththegedara's research focuses on the ecology, conservation and taxonomy of aquatic species. Dinesh GABADAGE is a field biologist. He studies the distribution of birds and mammals, and promotes wildlife conservation programmes in Sri Lankan communities. Madhava Botejue is the Regional Vice Chairman (South Asia \& Iran) of the IUCN Crocodile Specialist Group. His research focuses on the ecology, distribution and conservation of herpetofauna, avifauna and mammals. MAJintha MADAWALA is engaged in numerous habitat restoration and snake rescue programmes and is an active member of the IUCN Crocodile Specialist Group. Thilina Surasinghe's research interests include landscape-scale biodiversity conservation, freshwater ecology, and conservation of threatened species. 